\title{
The Role of the Library and Librarians in Promoting National Security in Nigeria
}

\author{
Ngozi Blessing Ossai-Ugbah
}

\author{
John Harris Library \\ University of Benin, \\ Benin City. Edo state, Nigeria \\ Email:ngozi4blessing@gmail.com
}

\section{Doi:10.5901/ajis.2013.v2n2p99}

\begin{abstract}
This paper examined the role of the library and librarians in promoting national security in Nigeria. The objective of the paper was to show that the library and librarians can contribute effectively in the fight against terrorism through effective propaganda; collection and dissemination of information; mobilizing the citizens through civic education and bridging of ideological and religious divides. The paper however stressed that national security is an all embracing term that deals with the protection of the interest of a nation. It is in this regard that the library has a social responsibility in national security. It recommended more government funding to achieve this task and re-organization of training curriculum of future librarians to include national security.
\end{abstract}

Keywords: Role, Library, Librarians; National Security, Nigeria

\section{Introduction}

Terrorism and militant insurgency around the world has assumed an alarming dimension. The bombing of the United States Embassy in Kenya and the air craft carrier USS Cole in Yemen, 12th October, 2000 appear to have been a catalyst for the sequence of events to follow. The attack killed 17 US sailors and injured 40 with Ibrahim al-Thawr and Abdullah al-Misawa as masterminds (http://news.bbc.co.uk/onthisday/hi/dates/stories/october/12/newsid 4252000 14252400.stm). On July 7th 2005 four bombs targeted commuters in London: three on underground trains, one on bus. The victims: 26 at Russell Square, 13 on bus at Tavistock Place, 7 at Aldgate, 6 at Edgware Road and the Suicide bombers: Hasib Hussain, Mohammad Sidique Khan; Germaine Lindsay and Shehzad Tanweer (http://news.bbc.co.uk/2/shared/spl/hi/uk/05/london_blasts/what_ happened /html/). Since the 9th September 2001 bombing of the twin towers, world trade centre in New York and the target of the Pentagon in the United States of America by Al Qaeda, terrorist attacks have been on the rise around the world. The stories of terrorist attacks by Chechnya rebels on 9th December, 2009 of Moscow train subway (Loiko, 2009), Taliban in Afghanistan are just a mention of few. All these were foreign to Nigeria and Nigerians until the attacks by Movement for the Emancipation of the Niger Delta (MEND) and the Islamic sect Boko Haram (Western Education is Nonsense) in Nigeria. Activities of the group spread across kidnapping of people; blowing up oil pipelines; bombing the United Nations building in Abuja, (26th August, 2011), the Nigerian Police Headquarters in Abuja (16th June, 2011), the Christmas day bomb blast at St Theresa Catholic Church, Madalla (25th December, 2011), AIG Police headquarter, Kano (20th January, 2012) and Army 1st Division Base, Kaduna (7th February, 2012) and blowing up of Agip gas pipeline. All these and several others in Jos; Damaturu, Sapele; Yenogoa; Bauchi, Kano and Kaduna has brought Nigeria and Nigerians to the reality of terrorism and the need for national security in Nigeria's national discourse (Agbambu \& Okeke, 2012; http://www. punchng.com/business/apointments-managements/nim-laments-incessant-bombings-in-nigerial;http://www.reuters.com larticle/2011/12/5/us-nigeria-blast-idUS TRE7BO03020111225). It is in this regard that the library has a role to play in national security in Nigeria.

\section{Literature Review}

National security loosely defined refers to the protection of the interests of a country (http://dictionary.reference.com/browse/national+security). National security therefore embraces several elements that cut 
across military, economic, social, religious and political sense to mention a few. There are very few literature that deals directly with the subject of this work. Some others are only gleanings around the subject that can breed insecurity and the roles of library and librarians in such context. Starr (2004) "libraries and national security: a historical perspective" dealt with response of libraries and librarians to the United States Patriot act of 2001. The article contended that the act was unjust and libraries have a responsibility to protect right to free speech and access to information which the act prevents. Omopupa (n.d.) observed that libraries have a role to play in promoting peace and unity. The article happed on the need for information circulation leading to rural development and food security as a means to achieve this. Bhatti (2010) examined libraries and peace education in Pakistan. Bhatti explored: "using libraries as a platform for exploring the causes and effects of extremism, bringing about positive change in the societal thinking and attitude convincing the global communities that violence is not an intrinsic ingredient of Pakistani society and that all the contributory factors must be examined, is the basic motivation of this study." Kargbo (2004) examined the role of librarians in post war reconstruction in Sierra Leone. It recommended Librarians widening their scope of services to help make information available to people. Ndagana and Ogunrombi (2006) pointed out that Libraries create opportunities for youths to be employed especially in restive communities which in turn is a background for national security.

\section{Objectives}

The objectives of this paper are:

1. To reveal that the library and librarians as information collectors and disseminators have a role to play in the war on terrorism in Nigeria

2. To prescribe information provision as a crucial tool in national security

3. To x-ray the role of the library and librarians in national security.

4. To stress that the fight against terrorism and insecurity can be better fought and won through employing the services of information managers like Librarians.

\section{Traditional Roles of the Library and Librarians}

According to Ogunsola (2011): "traditionally libraries were collections of books, manuscripts, journals, and other sources of recorded information. In the last 50 years, libraries have increasingly developed into a provider of information resources and services that do not even require a building." The Library's traditional lasting objective is to provide access to relevant information resources. The aim of this is to give high value to the needs and expectations of users. Generating and sharing information is useless, if there's no way to locate, filter, organize and access it. Traditionally librarians are in the forefront of information dissemination and they will continue to be there (Ramos, 2007). Libraries collect, stock, process, organize, disseminate and distribute information/knowledge recorded in documentary and non-documentary sources/formats. Since knowledge and information are so vital for all round human development, libraries and other institutions that handle and manage knowledge and information are indeed invaluable in national security. According to John (1998): "of all the roles that librarians and libraries play two are critical to modern society as we know it. The first is the role of the library as the place where the information seeker can access information without restriction - the access role. The second role has been the world-wide effort of libraries to archive, protect and provide ongoing access to information and the world's cultural heritage for the long term - the preservation role. These two fundamental roles have differentiated libraries from all other institutions." In this vein to propose that libraries are "in the midst of a revolutionary phase, with new assignments crowding the librarian's agenda, is to state the obvious" (Mokogwu, n.d). This is where the civic and social responsibility of the library takes center stage.

Social responsibility is a part of librarianship (Kagan, 2005). The issue of national security is therefore core value of librarianship. Since no meaningful learning, education and development can take place in a context of insecurity and brazen destruction of lives and properties, the onus lies on the library for responsible librarianship through dissemination of information that can contribute to peace and national security in Nigeria by helping the citizens to understand their role in national security. The library as a storehouse of information has positively altered its scope of influence across time to become not only a place that houses books but a gateway through which information can be conveyed to people irrespective of location.

Librarians have traditionally been concerned with certain functions. Rowland (1998) lists some of these as:

1. Collection development and acquisitions. 
2. Cataloguing and classification.

3. Circulation.

4. Referencing and,

5. Preservation, conservation and archiving

Since the inception of the human race various service oriented sectors have transformed in many ways. This is because services to humanity ought to also adapt to change and reflect the present conditions and status in today's society. Issa (2003) pointed out that economic and national power and status for instance are leveraged on the widespread use of information and knowledge which the library provides. Agreed that the responsibility of library and information services rests on the librarian and information scientists, there is also the need to collaborate with the security agencies in bringing maximum information services to the public and in this case for national security.

\section{The Roles of the Library and Librarians in National Security}

Historically, libraries have always been a key contributor to national development and it is appropriate that they take a leadership role in the current movement on national security. The word 'national security' is used by politicians and military leaders in the line of a policy objective. However, national security loosely defined refers to the protection of the interests of a country (http://dictionary.reference.com/browse/national+security). This is where it takes a wide meaning as all embracing dimension of national life (Hussain, 2008 and Iradia, 2011) because threat posed to any element of national power creates security problems. The role of the library in national security is not just to spread information in a particular area but to offer a holistic approach, around all aspects of the policies of the country called Nigeria. Currently, the war on terror and terrorism is not only fought by the armed forces but the whole nation is engaged in the economic, scientific, political and social activities and happenings in all practicable fields of life. For the library, this is a feasible objective, which is achievable through the information and dissemination process of the library (Hali, 2003).

"National security is the requirement to maintain the survival of the state through the use of economic, diplomacy, power projection and political power" (http://en.wikipedia.Org/wiki/ National_security). Information is therefore a crucial factor in national security. This is because the line between security and insecurity lie in information given or information withheld. The ability to use information and its associated tools is a source of power for any nation (Bordbar, n.d.) which the library and librarians are best equipped to do. In Nigeria's current security challenge, citizens and government must recognize this need for information use and literacy as a means of national security (Noruzi, 2006). Information remains the only product which the library handles and this includes all media in which the information is shaped. The only means through which the real integration of people living in political, economic, religious and ideological poles could be brought together is through the actual cooperation and exchange of vital information between the two: the terrorist and the terrorized.

The philosophy behind the library and its services is based on information collection, categorization, conservation, and management. At this time, when Nigeria is still in democratic embryo, ideological divides which is the threshold upon which terrorism thrives can be countered through effective information dissemination. There is an urgent need for provision of "right information, in the right format, for the right people, at the right time, and in the right place" to stem the tide of ignoramus decadence. The long years of political and religious distrust in the country has fanned the flames for crises that have polarized the society and divided Nigerians across ethno-religious lines. To allow every Nigerian to read from the same page, it is important to flash the searchlight of information dissemination on restive areas so that they cannot be used to destroy the hard earned peace and unity the country is presently enjoying.

As Ogunsola observed (2011):

Librarianship has undergone a radical change in recent years, which will be continued in the future. As libraries have changed, so too, has the role of the librarian. Increasingly librarians have assumed the role of educator to teach their users how to find information both in the library and over electronic networks. Public librarians have expanded their roles by providing local community information through publicly assessable computing systems. Some librarians are experts on computers and software. Others are concerned with how computer technologies can preserve the human cultural records of the past or assure that library collections on crumbling paper or in old computer files can still be used by people many centuries in the future. The work of librarians has moved outside library walls. Librarians have begun to work in the information industry as salespeople, designers of new information systems, researchers, and information analysts. They are also found in such fields as marketing and public relations and in such organizations as law firms, where staffs need rapid access to information. 
Though information officers and librarians may not be military people, because of their professional background, they are usually equipped to provide technical information services to experts in other fields using the language they understand most since language is a synergy. In providing information services, librarians may need to adopt campaigning or mobile libraries to bring library services to the doorsteps of citizens to educate them on national security. Nwalo (2003) observed that the compilations made by mobile libraries reflect perceived needs of local communities. This will help to provide security services to communities and help citizens and patrons of the library attain maximum information services, in spite of their vocations. Ifidon and Ahiauzu (2006) observed defined information as "structured data that causes a human mind to change its opinion about the current state of real world and contribute to a reduction in the uncertainty of the state of the system". Since information is a transformation agent, a shaper of perspectives and philosophies of life, the onus lies on libraries as information centers and librarians as information managers to ensure that Nigerians have access to information that will direct their actions. Some Nigerian who participated in protests across the country are uninformed as seen in the fuel subsidy protest of 9th - 15th January 2012 (NTA News Bulletin, 13th January, 2012). Information therefore is a sine qua non for individual and collective freedom and attainment of national security. Anasi (2010) citing Sokari (2006) agrees that "information is necessary for people to be liberated from the shackles of ignorance, misconceptions, economic stagnation, social unrest, and political instability. Social cohesion cannot be achieved without timely, accurate, and relevant information." This is because information is fresh ideas or fact taken out of a person's surrounding for use with the objective of transforming behaviour in all areas of human life (Ajegbomogun, 2008). Information helps create enlightened and responsible citizens. The library is the gateway to information. It is a place where information is acquired, processed, repackaged, preserved, and disseminated (Anasi, 2010).

Currently, electronic media is one of the most effective and powerful means of mass mobilization. A nation not mobilized enough to withstand terrorism cannot aspire to preserve its freedom, faith and ideology for long. On the other hand, strongly mobilized people cannot be forced to abandon their security in the face of terrorism. It is in this regard that libraries and librarians can ginger up the electronic media to promote and expand security awareness among the people at large. The library through the media has been waging war of its own to counter the hostile propaganda from insurgents and terrorists in Nigeria. Like their names suggests propaganda: Movement for the Emancipation of the Niger Delta (MEND) and Boko Haram (Western Education is nonsense), the government through the library can fund effective counter propaganda campaigns that will sensitize the citizens to the ills of terrorism and win over their sympathizers. One of the most effective means of maintaining national security is through propaganda and the primary tool of propaganda is the media. Some of the techniques adopted in a conflict to gain the desired results are repeating the lies of the terrorists, attacking personal opinions disguised as fact, headlining propaganda, selective control of information and the yellow journalism (Gamble and Kwerliambli, 1990). Thus, the role played by the library and librarians is a morale-boosting role. "In the military parlance, morale is the will to fight for the national cause to the last" (Hussain, 2008). Thus, in the war on terror, psychological operation is not the only function which the library can perform in the context of national security; it can act as a bridge between the armed forces and the people (Hali, 2003).

The library provides not only information resources and guidance, but it is also a judgment-free zone in which a citizen can investigate interests of the terrorists without worry of embarrassment or exposure. A greater understanding of the differences and similarities between peoples of the world can potentially initiate and expand feelings of tolerance and empathy for cultures, religions and traditions outside of one's immediate sphere. This the library can provide. Omotayo (2005) noted that: "in war situations in enlightened societies, use of libraries increases as users flock to libraries to find information to guide them. Information that can promote peace, unity, progress, peaceful co-existence, and harmonious relationship among all the communities must therefore be available in libraries. Librarians, therefore, in promoting access to this information, act as agents of the promotion of communal peace and reconciliation."

The importance of libraries to the Nigerian society can be seen through the statistics of people who use the library to gain access to print media. The majority of people who use libraries usually do so through the public or university library system in their communities. People throughout the country rely on public or university libraries as a provider of access to print and electronic information, access to email, assistance with information gathering and leisure reading (Becker, 2003). Some people choose to only engage the world through information sources that reinforce their views and reassure them that the world is exactly as they perceive it to be. Others are overly curious and want to know everything they can about everything no matter the barriers they face. It is the people who fall in the middle that are truly helped by the library and librarians. An individual may at some point have questions about current events, people or cultures outside of their own immediate experience, religion or ethnicity. Their desire for information might be driven by a school project, a story on the news or by simple curiosity. Curiosity and the desire to learn about the world can be protected and nurtured 
by the library. The freedom to explore and read about other cultures is vital to national security, especially as a tool to mitigate and prevent radicalization. The library and librarians indeed have a role to play in national security.

\section{Recommendations}

This paper recommends that:

1. Security agencies should as a matter of deliberate government policy work closely with librarians in the war against terror;

2. Libraries and librarians should be in the forefront of national security discourses through sponsorship, guiding principle and act can further the country's national security

3. The Library and Librarians open public reading centers where people can have ease of access to right information

4. The Library and Librarians should explore the use of printing and pasting posters in public places to sensitize the public to the disastrous effects of national insecurity,

5. The library in the rural areas for instance be employed to distribute literacy materials that will help people to be better functional information managers;

6. Librarians and libraries should design a blueprint for security consciousness.

7. The curriculum of various degree and non-degree awarding institutions should be redesigned to accommodate issues on national security for all students;

Libraries in Nigeria could seek assistance in terms of funds and technical support from other countries where terrorism is on the boil.

\section{Conclusion}

Despite the shadowy light of importance cast over libraries and librarians, they still serve a needed role in Nigeria and are utilized regularly by patrons seeking information (Ossai-Ugbah, 2009). It may be that the majority of government policy makers and drafters are unaware of what the government can achieve through the library as a base for information transactions. On the other hand, it may be that many are willing to trade their rights to privacy, free speech and unhindered intellectual pursuits for a sense of security. Libraries and librarians should be seen as important tools in national security. National security is possible through the utilization and collaboration of library, human, and material resources.

\section{References}

Agbambu, Chris \& Okeke, Christian (2012). Boko Haram Amoury Uncovered in Kano and Security Task force reveals names of Agip Brass-Bonny pipeline attackers." Nigerian Tribune. http://tribune.com.ng/ index.php/front-page-news/35718-boko-haramsarmoury-uncovered-in-kano-security-task-force-reveals-names-of-agip-brass-bonny-pipeline-attackers-nigeria-eu-to-engage-antiterrorism-experts-on-boko-haram

Audunson, R. (2005). The public library as a meeting-place in a multicultural and digital context- The necessity of low-intensive meetingplaces. Journal of Documentation. 61(3): 429-441.

Anasi, Stella N.I. (2010). Curbing Youth Restiveness in Nigeria: The Role of Information and Libraries. Library Philosophy and Practice . http://unllib.unl.edu/LPP/lpp2010.htm

Becker, Patti C. (2003). "In time of war: When the nation is in crisis, America's libraries respond." American Libraries. May, 34(5): 54-57.

Berninghausen, David K. (1950). "The responsibilities of Librarians." American Library Association Bulletin. 44(8): 305-306.

Bhatti, Rubina. (2010). Libraries and Education for Peace in Pakistan. Library Philosophy and Practice. http://www.webpages.uidaho.edu/ mbolin/bhatti4.htm

Bordbar, S. (2000) Information systems and accessing human knowledge. Ettela'resani journal. Iranian Information \& Documentation Center (IRANDOC). (Persian language).

Chadwell, Faye A. (2002). "Intellectual freedom, an evolving and enduring value of librarianship." OLA Quarterly. Spring, 8(1): 18-23.

Echezona, R.I. (2007). The role of libraries in information dissemination for conflict resolution, peace promotion, and reconciliation. African Journal of Libraries, Archives, and Information Science. 17 (2): 143-152.

Elisabeth Jones. (2009). "Reinventing Science Librarianship: Themes from the ARLCNI Forum." Research Library Issues: A Bimonthly Report from ARL, CNI, and SPARC. February 262: 12-17. http://www.arl.org/resources/pubs/rli/.

Gamble, Michael W. and Kwerliambli, Teri. (1989). Introducing Mass Communications. Singapore: Mc-Graw Hill. 
Hali, Sultan, M. (2003). Media Imperialism. The Defence Journal. March 24.

Hayden, Carla D. (2003). "What are libraries for?" American Libraries. November, 34(10): 5.

Hussain, Nazir (2008). The Role of Media in National Security. A Case Study of 1998 Nuclear Explosions by Pakistan. South Asian Strategic Stability Institute (SASSI). London. .http://www.isn.ethz.ch/isn/Digital-Library/IR-Directory/Detail/?ots591=0c54e3 b31e9c-be1e-2c24-a6a8c7060233\&lng=en\&id=95631

Ifidon, S.E., \& Ahiauzu, B. (2005). Information and conflict prevention in the Niger Delta Region of Nigeria. African Journal of Libraries, Archives, and Information Science. 15 (2): 125-132.

Issa, A. O. (2003). A Beginner's text on librarianship. Ilorin: Wumi Commercial Press.

Iredia, Tonnie, (2011). "What is national security"? http://www.vanguardngr.com/2011/12/what-is-national-security/

John, Nancy. (1998). Libraries and the global information infrastructure. www.unesco.org/webworld/ infoethics2/eng/papers/paper_13.rtf

Kagan, Al. (2005). "IFLA and Social Responsibility: A Core Value of Librarianship." In Libraries, National Security, Freedom of Information Laws and Social Responsibilities: IFLA/FAIFE World Report. Ed. Susanne Seidelin and Stuart Hamilton. 33-43. Copenhagen: IFLA/FAIFE.

Kargbo, J.A. (2004). Effects of the Civil War and the Role of Librarians in Post-War Reconstruction in Sierra Leone. World Libraries. 12(2). http://www.worlib.org/ vol12no2/kargbo_v12n2.shtml

Krolak, Lisa. (2006). The role of libraries in the creation of literate environments. "Paper commissioned for the EFA Global Monitoring Report 2006, Literacy for Life". http://www.unesco.org/education

Loiko, Sergei L. (2009). "Chechen rebels claim Russia train bombing." Los Angeles Times. http://articles.latimes. com/ 2009/dec/03/world/la-fg-russia-chechens3-2009 dec03

London Blasts. http://news.bbc.co.uk/2/shared/spl/hi/uk/05/london_blasts/what_happened/ html/

Mokogwu, W.O (n.d.) "Functions of the Library." www.idahosauniversity.com

"National Security." http://dictionary.reference.com/browse/national+security

Nazir, Hussain. (2008). 'Rethinking the South Asian Security: Traditional and Non-Traditional Paradigm Debate.' Massarrat Abid and Qalb-i-Abid ed., South Asia: Politics, Religion and Society. Lahore: Pakistan Study Centre, University of the Punjab.

Ndagana, B.L., \& Ogunrombi, S.A. (2006). Blazing the trial in poverty alleviation among students in Nigeria: The Federal University of Technology, Yola. Library Philosophy and Practice. 9(1). Available: http://unllib.unl.edu/LPP/ndagana.htm

Noruzi, A. (2006). Where is the station of knowledge (libraries) in scientific and economical development? Available: http://nouruzi.persianblog.ir/post/233 (Persian language).

Nwalo, K. I. N. (2003). Fundamentals of library practice: A manual on library routine. Ibadan: Stirling Horden.

Ogunsola, L.A. (2011). The Next Step in Librarianship: Is The Traditional Library Dead? Library Philosophy and Practice. http://unllib.unl.edu/LPP/

Omotayo, B.O. (2005). Women and conflict in the new information age: Virtual libraries to the rescue. A paper presented at the world Library and Information Congress: 71st IFLA General Conference and Council August 14th, 2005, Oslo, Norway.

Persson, Roland (2003). Traditional and modern in the library world. Scandinavian Public Library Quarterly. 36(1). http://www.splq.info/issues/vol36_1/09.htm

Ramos, Mila, M. (2007). The Role of Librarians in the 21st Century. Paper delivered during the 35th ALAP Anniversary Forum. http://www.slideshare.net/plaistrlc/the-role-of-librarians-in-the-21st-century

Rowland, Fytton. (1998). The Librarian's Role in the Electronic Information Environment. Paper presented to the ICSU Press Workshop, Keble College, Oxford, UK, 31 March to 2 April 1998. http://www.bodley.ox.ac.uk/icsu/ rowlandppr.htm

September, P.E. (1993). Promoting information literacy in developing countries: A case study of South Africa. African Journal of Library, Archives and Information Science. 3(1): 11-22.

Sokari, U. (2006). The role of library and information management in the promotion of information literacy in the 21st century in Nigeria. International Journal of Research in Education. 3 (2): 176-181

Starr, Joan (2004), Libraries and National Security: An Historical Review. First Monday. 9 (12)-6. http://firstmonday.org I htbin/cgiwrap/bin/ojs/index.php/fm/article/viewArticle/1198/1118

Omopupa, K. T. (2003). The libraries of Nigeria and their role in promoting peace, unity, and rural development. www.kit.nl/portals/documents/query.ashx?RecordID

Ossai-Ugbah, Ngozi, B (2009). "Library use patterns of law students at the University of Benin, Benin City, Nigeria," Simbiosis: Journal of Graduate School of Information Science. University of Puerto Rico, 6, (1): 1-17.

USS Cole. (2000). http://news.bbc.co.uk/onthisday/hi/dates/stories/october/12/newsid_4252000/4252 400.stm 